\title{
Effectiveness of the Finger Handheld Relaxation and the Self-Tapping Relaxation Technique on Dysmenorrhea Pain in Nursing Students

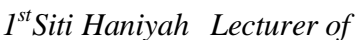 \\ Program of Harapan Bangsa University \\ Central Java, Indonesia \\ haniwiyana56@gmail.com
}

\author{
$2^{\text {nd }}$ Prasanti Adriani \\ Lecturer of Nursing of Harapan \\ Undergraduate Midwifer Program of Harapan Bangsa \\ University \\ Central Java, Indonesia \\ pra.adriani@gmail.com
}

\begin{abstract}
Management of dysmenorrhea pain is very important. One of them is using non-pharmacological techniques, which are finger handheld relaxation pain sensations and deliver the transmission of pain impulses to the brain. Self-tapping is tapping touch which is done independently. Self-tapping can apply basic touch techniques to yourself and doesn't require a lot of money. The purpose of this study was to determine the effectiveness of hand-held relaxation techniques against dysmenorrhea pain in the second semester Nursing Students of Harapan Bangsa University. Design This study was a quasipretestposttest experimental design with control groups using a sample of 72 respondents divided into 3 groups, 24 respondents used Self Tapping, 24 respondents used Finger Handheld Relaxation technique and a control group of 24 respondents. To find out the decrease in pain scale in the treatment group, the researchers used the Paired T test and to find out the effectiveness of hand-held relaxation technique towards dysmenorrhea pain in the second semester Nursing students of Harapan Bangsa University, Independent Sample T Test was employed. Self- Tapping effectively reduces dysmenorrhea pain in Semester II Nursing students with p-value 0.00. Finger Handheld Relaxation Technique was effective to reduce dysmenorrhea pain in the second semester Nursing students with a p-value of 0.00
\end{abstract}

Keywords: finger handheld relaxation, self-tapping dysmenorrhea

\section{INTRODUCTION}

When dysmenorrhea occurs, women will feel pain and the impact of pain will result in limited mobilization, Activity of Daily Living (ADL) is disrupted due to increased pain intensity when moving. The incidence of dysmenorrhea in adolescents in Asia is $74,5 \%$. Hispanic teenage girls have a prevalence of dysmenorrhea of $85 \%$, while the incidence in Indonesia is $55 \%$. Seeing these data can be interpreted that almost all women have experienced dysmenorrhea [1]

Efforts to manage pain in dysmenorrhea are using pharmacological and non-pharmacological methods.
Pharmacological pain control is effective for moderate and severe pain. Pharmacology is not intended to improve the ability of the client to control his pain, so a pharmacological combination is needed to control pain with non-pharmacology so that pain sensation can be reduced and the recovery period does not extend[2]

Non-pharmacological treatment that can reduce pain, can also start from simple, such as compressing with hot temperatures to hypnosis. One nonpharmacological treatment that can reduce pain is selftapping therapy. Self-tapping is tapping touch which is done independently. Self-tapping can apply basic touch techniques to yourself and doesn't require a lot of money. Tapping Touch is a holistic treatment technique using touch and rhythm. Although it was made easy to learn and simple to do, Tapping Touch was developed through the integration of therapeutic elements which proved to be effective through clinical and research use [3].

Finger Handheld relaxation technique is an easy way to manage emotions and develop emotional intelligence. Along our fingers there are energy channels or meridians connected to various organs and emotions [4]. Grasping a finger while breathing deeply (relaxation) can reduce and heal physical and emotional tension, because the grip of the finger will warm the points of entry and entry of energy to the meridians (energy channels) located on our fingers [5].

Harapan Bangsa University has also been used as a place for research on the reduction of dysmenorrhea pain such as drinking turmeric acid, Ar Rahman murotal therapy, yoga, progressive muscle relaxation \& aromatherapy, deep back massage, hypno-analgesia and Mozart classical music therapy, but for complementary self-tapping and relaxation therapy Finger Handheld Relaxation have never been done.

Based on pre-survey on level I Nursing DIII students and SI Nursing, 120 female students had dysmenorrhea. In addition, the female students did not know about self-tapping therapy and Finger Handheld 
distributed then using the Paired T test. To find out the difference in pain scale between the control group, with the intervention group if the data distribution was normal using the Independent $\mathrm{T}$ test. To find out the difference in pain scale between the control group, with the intervention group 1, 2 using One Way ANOVA.

\section{RESULT AND DISCUSSION}

Characteristics of Respondents in general, the characteristics of respondents described in this study were age and information about RGJ (finger handheld relaxation) and self-tapping

\begin{tabular}{|l|l|l|l|l|l|l|l|}
\hline \multicolumn{2}{|l|}{ Characteristic s } & \multicolumn{2}{l|}{ RGJ } & \multicolumn{2}{l|}{$\begin{array}{l}\text { Self- } \\
\text { Tapping }\end{array}$} & \multicolumn{2}{l|}{ Control } \\
\cline { 2 - 9 } \multicolumn{2}{|l}{} & F & $\%$ & f & $\%$ & F & $\%$ \\
\hline Age & 17 year & 1 & 4.2 & 1 & 4.2 & 0 & 0 \\
\cline { 2 - 9 } & 18 year & 12 & 50 & 12 & 50 & 7 & 29.2 \\
\hline & 19 year & 10 & 41. & 10 & 41.6 & 13 & 54.1 \\
\hline & 20 year & 1 & 4.2 & 1 & 4.2 & 4 & 16.7 \\
\cline { 2 - 9 } & Total & 24 & 100 & 24 & 100 & 24 & 100 \\
\hline $\begin{array}{l}\text { Infor } \\
\text { mati } \\
\text { on abou } \\
\text { t } \\
\text { RGJ } \\
\text { and Self } \\
\text { Tapp } \\
\text { ing }\end{array}$ & Neve r & 0 & 0 & 0 & 0 & 0 & 0 \\
\cline { 2 - 8 } & Yet & 24 & 100 & 24 & 100 & 24 & 100 \\
\hline & 24 & 100 & 24 & 100 & 24 & 100 \\
\hline
\end{tabular}

Effectiveness of self-tapping technique and finger handheld relaxation technique on pain dysmenorrhea in the second semester students at Harapan Bangsa University

\begin{tabular}{|l|l|c|c|}
\hline \multicolumn{1}{|c|}{ (I) Treatment } & \multicolumn{1}{c|}{$\begin{array}{c}(\mathrm{J}) \\
\text { Treatment }\end{array}$} & Std. Error & $p$ value \\
\hline \multirow{2}{*}{ Control } & Self-Tapping & 0,516 & 0,07 \\
\cline { 2 - 4 } & FHR & 0,500 & 0,00 \\
\hline \multirow{2}{*}{$\begin{array}{l}\text { Self-Tapping } \\
\text { finger } \\
\text { handheld } \\
\text { relaxation (FHR, }\end{array}$} & Fontrol & 0,516 & 0,03 \\
\cline { 2 - 4 } & Self-Tapping & 0,500 & 0,07 \\
\cline { 2 - 4 } & 0,500 & 0,00 \\
\hline
\end{tabular}

Based on table, it can be seen that the result of the ANOVA test obtained was the value of $\rho$-value of selftapping techniques with finger handheld relaxation technique of $0.07, \rho$-value of self-tapping technique with control of 0.03 and $\rho$-values between finger handheld relaxation technique finger with control was 0.00 .

Based on the above results, it can be concluded that there was an influence between self-tapping on dysmenorrhea pain with a value of $\rho$-value 0.03 and 
there was an influence between finger handheld relaxation techniques on dysmenorrhea pain with a value of $\rho$-value of 0,000 . Based on the ANOVA test results, it can also be seen that the finger handheld relaxation technique was not more effective than selftapping towards dysmenorrhea pain due to the $\rho$ value of 0.07 or $(0.07>0.05)$.

Primary dysmenorrhea pain levels before and after selftapping, according to the theory, pain is an unpleasant sensory and emotional experience and is associated with tissue damage, both actual and potential damage. It is very subjective because the feeling of pain is different in each person in terms of scale or level and only that person can explain or evaluate the pain they experience [6]

Generally, dysmenorrhea pain arises due to endometrium producing prostaglandin $\mathrm{F} 2$ which causes movement of smooth muscles. If an excessive amount of prostaglandin is released into the bloodstream, it will cause pain during menstruation [7] In line with research conducted by Sirait (2018), it shows that dysmenorrhea sufferers with mild pain scale were 8 people $(32.0 \%)$ and dysmenorrhea sufferers with moderate pain scale were 17 people $(68.0 \%)$, while patients with severe dysmenorrhea were nothing. Research conducted by researchers, began by interviewing respondents about the experience of perceived dysmenorrhea pain, then the researcher gave a sheet of procedures for implementing self-tapping techniques and demonstrated them and provided a coherent explanation. Then the researchers asked respondents to measure the scale of dysmenorrhea pain felt by the respondent before (pretest) self-tapping technique was done by using the Numeric Rating Scale (NRS). In theory, self-tapping therapy is beneficial for reducing pain. Because being comfortable is basic, so choose the rhythm and location to knock

comfortably[3]

According to research conducted by Sirait (2018) shows that the number of respondents' pain scales after self-tapping was a mild pain scale of 25 people (100\%) and the pain scale was nothing. Respondents with moderate pain scale were respondents with severe pain before self-tapping. After self-tapping technique, respondents stated a decrease in the level of pain felt. The lower abdomen that was previously cramping became more relaxed.

The finger handheld relaxation technique is an easy way to manage emotions and develop emotional intelligence. Emotions are like waves of energy flowing in the body, mind and soul. When we feel excessive feelings, the flow of energy in our body becomes blocked or blocked, so that it will produce pain or congestion. Along our fingers there are energy channels or meridians connected to various organs and emotions [4]. Grasping a finger while breathing deeply (relaxation) can reduce and heal physical and emotional tension, because the grip of the finger will warm the points of entry and entry of energy to the meridians (energy channels) located on our fingers [5]. The relaxation response is part of a general decline in cognitive, physiological, and / or behavioral stimulation. The relaxation process also involves a decrease in pain stimulation.

According to the theory of acupuncture, each finger is a pathway for the entry of energy and is associated with certain emotions. there are many points around the fingers and palms. Based on the concept of Gate Control Theory, tactile fiber stimulation of the skin can inhibit pain signals from the same area of the body or other areas. Finger Handheld Relaxation is a light touch and massage technique, which can normalize heart rate and blood pressure, and improve the condition of relat in the body by triggering comfortable feeling through the acupuncture points on the surface of the fingers. This technique facilitates distraction and decreases sensory transmission of stimulation from the abdominal wall thereby reducing discomfort in the affected area. According to the theory, there are several ways to deal with dysmenorrhea pain where by pharmacological and non-pharmacological therapies. The way to overcome dysmenorrhea is by resting, sleeping, drinking herbal medicine, taking medicine, and there are also those who treat dysmenorrhea by drinking warm tea, smeared with eucalyptus, tailbone stretches and compressed with hot water [8] and [1].

Most of the research respondents in the control group in dealing with dysmenorrhea in accordance with the theory. Before given pain relief, most respondents mentioned that the pain felt was sometimes quite severe. Respondents felt a contraction in the lower abdomen.

In this study, the control group was not given an intervention or there was no treatment at all. Thus, respondents who usually use pain-reducing, in the control group did not use pain-reducing at the time the dysmenorrhea appeared.

The purpose of self-tapping is to eliminate physical tension, provide a feeling of comfort and new energy, reduction of physical pain and fatigue, reduction of physical stress symptoms, the activation of the parasympathetic nervous system and an increase in the hormone serotonin [3]. Self-Tapping mechanism in order that the pain can reduce because according to recent research conducted at Toho University in Japan about the effect of tapping therapy on the hormone serotonin shows the results of tapping therapy can increase the hormone serotonin. Serotonergic (5-HT) neurons are known to play a role in relieving anxiety, pain, tension and depressive symptoms in humans [9]. Self-Tapping or Tapping Touch is a therapy that involves rhythmic behavior, namely by doing rhythmic touch using the right and left fingers pads in turn. The presence of these rhythmic movements causes an increase in serotonin secretion. 
the lower part of the back and placing the hand on the lower abdomen

[3]

Research conducted by Akbar, Lismidiati \& Santi (2017), to compare pain reduction in the intervention group and the control group, showed the results that self-tapping intervention was more effective in reducing the level of primary dysmenorrhea pain in female students of PSIK FK UGM with a p-value $<0.01$. In addition, research conducted by Ulaa (2017) stated that statistically yoga and self-tapping were equally effective in reducing the intensity of primary dysmenorrhea pain with p-values of 0,000 and 0.003 , respectively. From this study it can be concluded that there is a significant difference between the treatment group and the control group in decreasing the level of pain dysmenorrhea, where the treatment group is more effective in reducing pain than in the control group. The Effectiveness of Self Tapping and finger handheld relaxation Technique towards dysmenorrhea pain in the second semester Nursing Students at Harapan Bangsa University. Based on the research $\rho$-value $(0.28)$, both have differences with the control group in reducing pain. finger handheld relaxation technique and selftapping were found to be equally effective towards dysmenorrhea pain. Direct forms of massage such as counter pressure are very effective in dealing with abdominal pain during dysmenorrhea. Counter pressure can overcome sharp pain and provide pleasant sensations that fight discomfort during contractions or between contractions [10]. That way this pain impulse can be blocked by providing stimulation to large diameter nerves which causes the Gate Control to be closed and pain stimulation cannot be transmitted to the cerebral cortex

\section{CONCLUSION}

The mean score of dysmenorrhea pain in Nursing students in the second semester before was 5.42 and decreased after self-tapping to 2.46 with a $\mathrm{p}$ value of 0.00 . The mean score of dysmenorrhea pain in Nursing students of the second semester before was 4.50 and decreased after the finger handeld relaxation technique was 2.33. with a p-value of 0.00. SelfTapping effectively reduced dysmenorrhea pain in Semester II Nursing students with a value of p-value 0.00. Finger Handheld Relaxation Technique is effective to reduce dysmenorrhea pain in the second semester Nursing students with a p-value of 0.00. finger handheld relaxation Technique and self-tapping were found to be equally effective towards dysmenorrheal pain. the theory, there are eleven steps in self-tapping technique: jaw tapping, cheek pat, temple tapping (temple), forehead clap, head tapping, tapping the back of the head, tapping on the neck and shoulders, tapping the collarbone and chest, tapping the stomach, tapping

\section{REFERENCES}

[1] H. Setyowati, Akupresur untuk Kesehatan Wanita Berbasis Hasil Penelitian. Magelang, 2018. 
[2] J. Bobak, Lowderni, Buku Ajar Keperawatan Maternitas. EGC, 2012.

[3] I. Nakagawa, "Tapping Touch- Perawatan Holistik untuk Pikiran, Tubuh \& Planet," Tokishobo Books, Ed. Jepang, 2010.

[4] Cane, Sehat dan Selaras: Penyembuhan Trauma. Yogyakarta, 2013.

[5] D. Haniyah, S \& Novitasari, Kategori Nyeri Dismenorea pada Santri Putri di Pondok Pesantren Al- Amin. Viva Medika, Volume 10, Purwokerto: Viva Medika, 2018.

[6] D. Ramadhani, A.N, Buku Saku Praktik Klinik Keperawatan Edisi Revisi. Jakarta, 2017.

[7] N. M. Laila, Buku Pintar Menstruasi. Yogyakarta, 2011.

[8] S. Proverawati, A \& Misaroh, Menarche Menstruasi Pertama Penuh Makna.

Yogyakarta, 2009.

[9] A. Madjid, Pendidikan Karakter Perspektif Islam,. Bandung, 2011.

[10] B. Lane, "Massage in childbirth: How touch can provide pain relief during labor.," 2009.

R. Mander, Nyeri Persalinan. Jakarta, 2003 